\title{
Bipolar patterns of intraspecific competition in bryozoans
}

\author{
David K. A. Barnes ${ }^{1, *}$, Piotr Kukliński ${ }^{2,3}$ \\ ${ }^{1}$ British Antarctic Survey, NERC, High Cross, Madingley Road, Cambridge CB3 0ET, UK \\ ${ }^{2}$ Institute of Oceanology, Polish Academy of Sciences, Marine Ecology Department, ul. Powstańców Warszawy 55, \\ Sopot 81-712, Poland \\ ${ }^{3}$ University Centre on Svalbard (UNIS), PO Box 156, Longyearbyen 9171, Norway
}

\begin{abstract}
Polar shores probably represent the most dynamic and extremely disturbed environments on the globe. Nevertheless intense battles amongst sessile organisms for space are commonplace on hard substrata, mainly between fast-growing pioneer species. In this study we examined spatial interactions in encrusting species at 3 sites within each of 2 high Arctic localities, Horsundfjord $\left(77^{\circ} \mathrm{N}\right)$ and Kongsfjord $\left(79^{\circ} \mathrm{N}\right)$ in Spitsbergen, and 2 Antarctic localities, Signy Island $\left(60^{\circ} \mathrm{S}\right)$ and Adelaide Island $\left(68^{\circ} \mathrm{S}\right)$. In both polar regions 1 to $11 \%$ of encrusting fauna were involved in intraspecific interactions. Intraspecific competition was common; it usually involved just 1 or 2 pioneer species, mainly ended in tied outcomes, and most variability was at a local scale. The proportion of intraspecific encounters varied considerably at local $(\mathrm{km})$ scales (19 to $99 \%$ intraspecific at different sites), reflecting an extremely patchy environment due to ice scour. Most intraspecific encounters resulted in ties (stand-offs) and again most variability was at a local scale. Many intraspecific encounters were constructive, forming large $\left(>1 \mathrm{~m}^{3}\right)$ foliaceous colonies (termed bioconstructions) whose 3D structures can harbour rich biotas. In other colonies intraspecific competition caused crowding and accelerated ovicell production (reproductive activity). Homosyndrome (fusion) was not observed in the Arctic and was rare in the Antarctic, where its frequency differed significantly between competitor identities. We found that the likelihood of meeting conspecifics versus other species and of tied outcomes in encounters was related to the performance of species in interspecific competition: ties were most common, and homosyndrome only occurred in poor competitors. In the context of rapid Arctic and west Antarctic warming and ice-loading of nearshore waters, we predict strongly changing patterns of intraspecific competition. Indeed we suggest that decreased patchiness of intraversus interspecific competition and decreased levels of intraspecific competition should be strong indicators of increases in surface water ice-loading from ice-sheet collapses.
\end{abstract}

KEY WORDS: Sublittoral $\cdot$ Benthos $\cdot$ Bioconstruction $\cdot$ Climate change $\cdot$ Homosyndrome

\section{INTRODUCTION}

On land, population regulation through intraspecific competition has been well studied. In the marine environment, organisms also compete for their share of limiting resources: food, mates or space for access to food or mates. This is best seen in sessile organisms, for which a most valuable resource is space. Competition occurs, whereby encrusters grow into each other, and as many such organisms are calcified competition is quantifiable over small-scale time and preserved in the fossil record to allow large-scale temporal patterns to be examined (see McKinney 1995). A most obvious starting point for investigation of pairwise competitive interactions is to quantify outcomes in time and/or space and interpret what these mean. Before this can be attempted, however, it is necessary to gauge what outcomes are possible.

Generally fights between animals that are mobile in any medium result in determinate outcomes (Wagnon 
et al. 1966, Clutton-Brock et al. 1979), i.e. one competitor 'wins' and the other 'loses'. The consequences of such outcomes depend on many factors, and in extreme cases result in death. There is, however, another possible outcome for a potential competitor, a draw or tie. Such an outcome was thought to be rare or even an artefact, but is now known to be common in certain sessile and colonial animals (Schmidt \& Warner 1986, Tanaka \& Nandakumar 1994, Bell \& Barnes 2004). In these animals, tied results can happen in a number of different ways: (1) a stand-off, whereby both animals cease fighting/growing along a common boundary; (2) mutual overgrowth, whereby each animal invades the space of the other with neither having a net gain; or (3) they undergo a degree of fusion, known as homosyndrome (Knight-Jones \& Moyse 1961), whereby the tissues of both animals become joined. On meeting conspecifics some encrusting species can grow against each other using the undersurface of opposing colonies as their substratum to form bilaminar structures. In all 3 cases, intraspecific meetings become constructive rather than competitive. This building feature of intraspecific meetings has been reported for other clonal taxa and seems to be common and ecologically important (Karlson 1999). In this study, we investigated how common intraspecific competition is in the polar nearshore benthic communities and the frequency of various outcomes.

Darwin (1859) believed that organisms of the same species should have the most similar requirements and thus the most intense levels of competition would be intraspecific. Some of the key studies of intraspecific competition for resources have been conducted in the intertidal zone (Connell 1961, Paine 1974), but subtidal studies have remained scant. Certain marine taxa have, however, proved particularly amenable to studies of competition (e.g. corals and bryozoans). Jackson \& Buss (1975) and Buss \& Jackson (1979) demonstrated the existence of 'intransitive' networks among tropical bryozoan species. Many other types of animal communities have since been found to be similarly structured, e.g. ascidians (Schmidt \& Warner 1986), corals (Chornesky 1989) and sponges (Bell \& Barnes 2004). Bryozoans have proved useful as model animals in the demonstration of large-scale patterns of competition over time (McKinney 1995) and space (Barnes 2002). Since Knight-Jones \& Moyse's (1961) work, we know more about fusion, relatedness and kin-recognition in bryozoans, although only in a few species such as Celleporella hyalina (Manríquez 1999). In contrast we know little more about intraspecific competition, since Stebbing's (1973) study, other than that its prevalence increases from the tropics towards the poles (Barnes 2000). Indeed, at high Antarctic and Arctic latitudes most competitive encounters in nearshore communities of encrusting organisms are intraspecific encoun- ters involving cheilostome bryozoans (Barnes \& Clarke 1998, Barnes \& Kukliński 2003). The only previous study to have specifically addressed intraspecific competition in high-latitude seas in any taxa is the preliminary investigation of patterns of intraspecific competition amongst Spitsbergen encrusting fauna by Barnes \& Kukliński (2004) (see also present Fig. 3).

In the present study, we investigate the prevalence of intraspecific encounters and their outcomes amongst littoral and sublittoral bryozoans at Spitsbergen, Svalbard, and in the Scotia Arc and Antarctic Peninsula. We test the hypothesis that the prevalence and outcomes of bryozoan intraspecific encounters do not differ (1) within or between polar regions or (2) among species.

\section{MATERIALS AND METHODS}

Study area and species. We selected 2 study localities in each of the Arctic and Antarctic regions. Within each locality we selected 3 sites, and within each site 2 collections were made at each of 2 depths. In the Arctic, the localities were Horsunfjord (H1, H2 and H3) and Kongsfjord (K1, K2 and K3) in West Spitsbergen (Fig. 1). The sea temperature at the time of material collection in July 2002 was $3^{\circ} \mathrm{C}$ (annual variation -1.8 to $4^{\circ} \mathrm{C}$ ), and salinity varied from 33 to $34 \mathrm{psu}$ (but this can drop rapidly during the June melt to $>25 \mathrm{psu}$, see Swerpel 1985 and Węsławski et al. 1988). The inner fjord is characterised by winter (mid-December to end of May) coverage of fast-ice (frozen sea surface) and is subject to ice scour from floating ice during summer months. The central and outer parts of the fjord are only occasionally covered with fast-ice (Węsławski et al. 1988). Oceanographic and seasonal aspects of Horsunfjord have been covered in more detail by Swerpel (1985) and Węsławski et al. (1988). Similarly, for details of biomass, biodiversity and competition on the intertidal and coastal boulders see Węsławski et al. (1993) and Barnes \& Kukliński (2003). By far the most abundant encrusting species was the cheilostome Harmeria scutulata Busk.

In the Antarctic, the localities were Signy Island (sites = Billies, Outer Island and Robin) and Adelaide Island (sites = MacKay Point, Rothera Point and Lagoon) (Fig. 2). The sea temperature at the time of material collection in July 2002 was $0^{\circ} \mathrm{C}$ (annual variation -1.8 to $2^{\circ} \mathrm{C}$ ) and salinity was $\sim 34 \mathrm{psu}$. All sites are typically covered by winter (May to September) fast-ice and are scoured by floating ice during summer months. The oceanography of the region has been described by Clarke et al. (1988), whilst biomass, biodiversity and community values for intertidal and coastal boulders are given in Barnes (2000) and Barnes \& Brockington (2003). The most abundant encrusting species was the cheilostome Fenestrulina rugula Hayward \& Thorpe. 

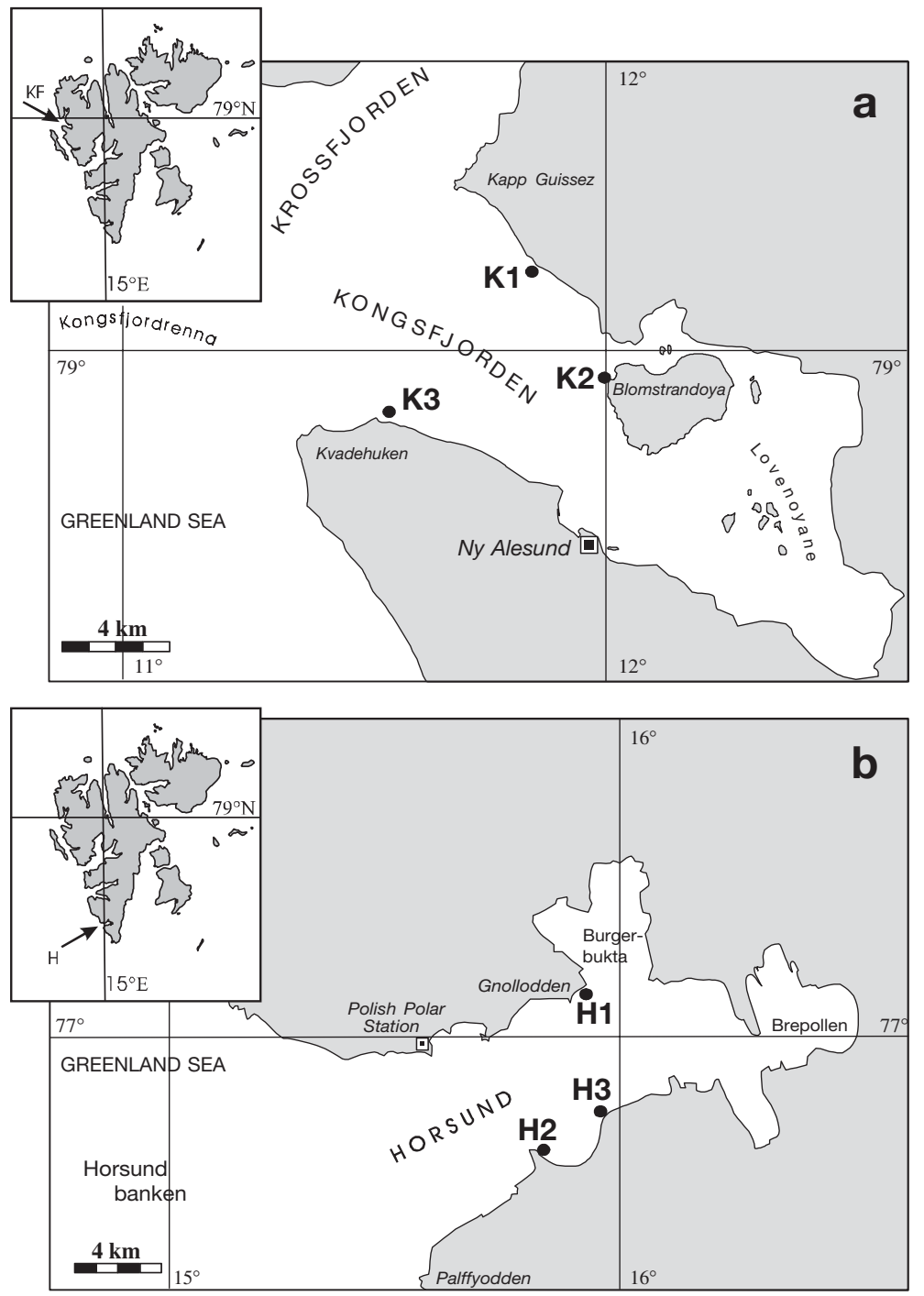

Fig. 1. Positions of Arctic study sites within 2 localities: (a) Kongsfjord and (b) Horsunfjord, West Spitsbergen tering intraspecific spatial competition, (2) the proportion of intraspecific (relative to interspecific) interactions, (3) the proportion of intraspecific interactions resulting in tied outcomes, and (4) the proportion of intraspecific interactions which resulted in fusion (homosyndrome). For statistical analysis the results of pairwise interactions were subdivided randomly such that the outcome of any given pair of competitors would not be used in more than 1 analysis, thereby giving independence to each data set. The data were arcsine-transformed prior to analysis using fully nested ANOVA in a random effects model. We also tried a fully nested ANOVA in a more complex mixed model with region, locality and site as random effects and depth as fixed effects (more specifically, depth is a repeated-measures factor). The output from both the random and mixed models was similar in terms of which factors were significant and how much variance they explained, so we report the simpler random model output only. In analyses, each replicate sample was the base unit, so all fully nested ANOVAs were based on sample sizes of 48 ( 2 regions $\times 2$ localities $\times 3$ sites $\times 2$ depths $\times 2$ replicates).

The procedure for testing the statistical significance of the variance components in Table 1 used ratios of successive mean squares (MS) in the nested-ANOVA table. The rationale of this approach follows from the expected squares for the 4 factors $\mathrm{C} 1$ to $\mathrm{C} 4$. To interpret Table 1, the variance $(V)$ components for regions, locality, site, depth and error (residual variance) are denoted by $V_{\mathrm{R}}, V_{\mathrm{L}}, V_{\mathrm{S}}, V_{\mathrm{D}}$ and $V_{\mathrm{e}}$, respectively. The expected MS are shown in Table $1 \mathrm{~b}$.
Protocol. We placed 2 quadrats haphazardly at each of 2 shallow sublittoral depths (6 and $12 \mathrm{~m}$ depth) at each site, at each locality in the 2 study regions. From within these, 50 boulders were randomly selected. The prevalence and outcomes of all intraspecific encounters were recorded together with the identity of the species involved. Interactions were, in accordance with the established literature (Sebens 1986, Tanaka \& Nandakumar 1994, Barnes 2002), scored as overgrowth (i.e. a win for one of the competitors) if the loser's feeding apparatus was obscured. A tied outcome was scored when (1) mutual, but equal, overgrowth took place, (2) skeletal build-up but no overgrowth (sometimes termed a stand-off) occurred, or (3) fusion (homosyndrome), where zooids of the 2 colonies coalesced, took place. A number of features of the data were calculated: (1) the probability of encoun-
Table 1. (a) Expected squares for 4 factors in a nested ANOVA table and (b) expected MS for error, depth, site, locality and region with associated degrees of freedom (df)

\begin{tabular}{|lcl|}
\hline (a) Factor & \multicolumn{2}{c|}{$\mathrm{MS}$} \\
\hline $\mathrm{C} 1$ & $1.00(5)+2.00(4)+4.00(3)+12.00(2)+24.00(1)$ \\
$\mathrm{C} 2$ & $1.00(5)+2.00(4)+4.00(3)+12.00(2)$ \\
$\mathrm{C} 3$ & $1.00(5)+2.00(4)+4.00(3)$ \\
$\mathrm{C} 4$ & $1.00(5)+2.00(4)$ \\
Error & $1.00(5)$ & \\
& \multicolumn{2}{c}{ Expected MS } \\
(b) MS & df & $V_{\mathrm{e}}+2 V_{\mathrm{D}}+4 V_{\mathrm{S}}+{ }_{1} 2 V_{\mathrm{L}}+24 V_{\mathrm{R}}$ \\
Region & 1 & $V_{\mathrm{e}}+2 V_{\mathrm{D}}+4 V_{\mathrm{S}}+12 V_{\mathrm{L}}$ \\
Locality & 2 & $V_{\mathrm{e}}+2 V_{\mathrm{D}}+4 V_{\mathrm{S}}$ \\
Site & 8 & $V_{\mathrm{e}}+2 V_{\mathrm{D}}$ \\
Depth & 12 & $V_{\mathrm{e}}$ \\
Error & 24 & \\
\hline
\end{tabular}




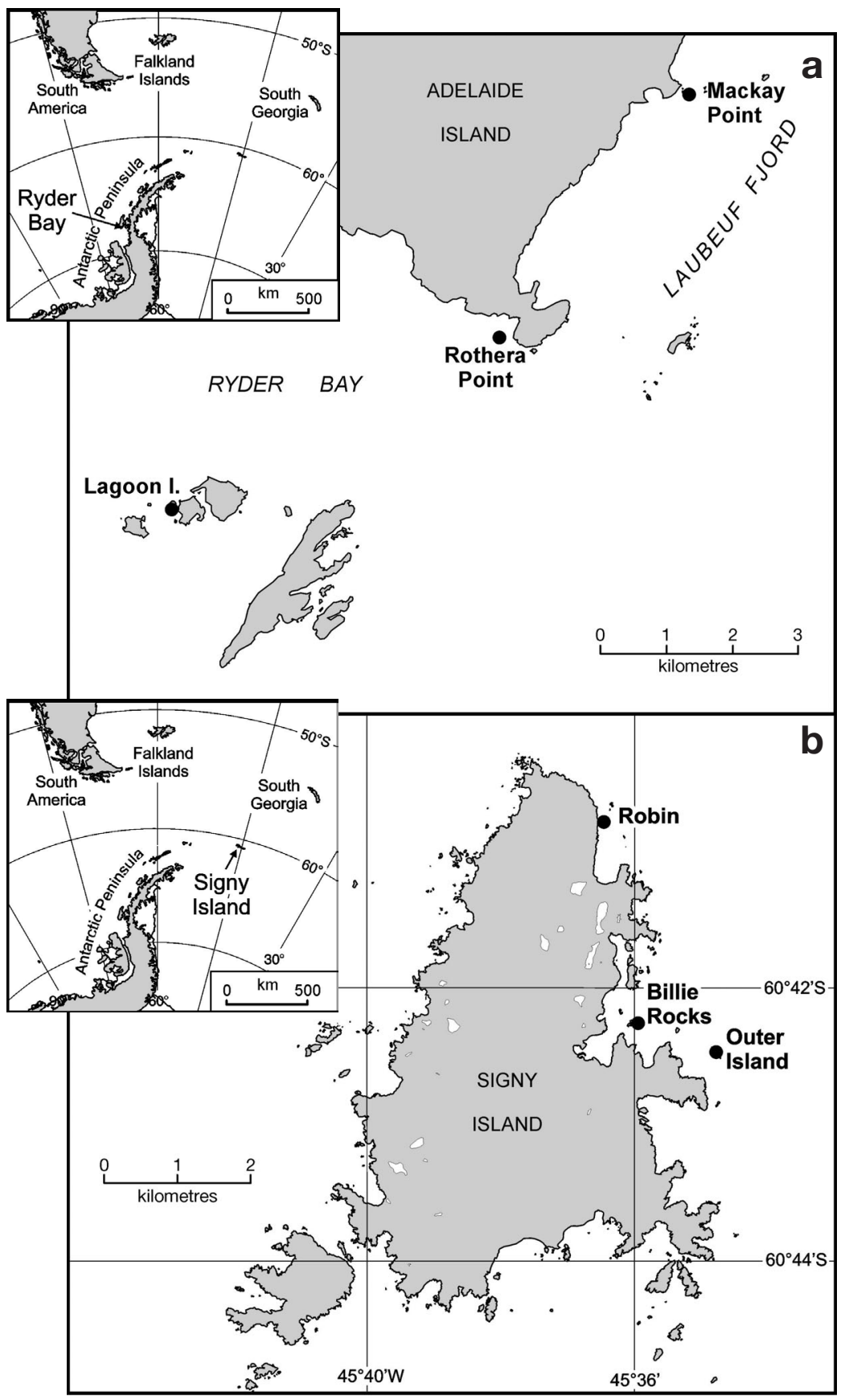

Fig. 2. Positions of Antarctic study sites within 2 localities: (a) Adelaide Island and (b) Signy Island in the Scotia Arc/Antarctic Peninsula region

sider the ratio $\mathrm{MS}_{\mathrm{Site}} / \mathrm{MS}_{\text {Depth}}$. For the null hypothesis, the expected value of the ratio is equal to 1 , irrespective of the value of $V_{\mathrm{D}}$. The ratios $\mathrm{MS}_{\text {Locality }} / \mathrm{MS}_{\text {Site }}$ and $\mathrm{MS}_{\text {Region}} /$ $\mathrm{MS}_{\text {Locality }}$ are then compared to test the locality and region components, respectively.

The same features of the data were calculated for a number of selected species (any that were involved in sufficient interactions) and plotted versus their performance in interspecific competition (competitive rank using data from Barnes \& Clarke 1998, Barnes 2000, Barnes \& Kukliński 2003, and authors' unpubl. sources). Competitive rank was determined using the proportion of wins to total interactions.

\section{RESULTS}

\section{Probability of intraspecific competition}

Recruitment and (potentially) competitive meetings in our shallow Arctic and Antarctic study regions were each dominated by single species of the cheilostomes Harmeria scutulata and Fenestrulina rugula, respectively. Thus, intraspecific encounters involving colonies of these species were the most common types of meeting and comprised the typical constraint for space in our shallow polar boulder communities. The frequency of intraspecific meetings in all study areas was low (see probabilities of intraspecific competition in Table 2), i.e. below $12 \%(p \leq 0.11)$ in all cases. This was not significantly different at the largest scale we studied, i.e. between the Arctic and Antarctic regions (Table 3a), nor were there significant differences at the smallest scale (within-site) but the probability of intraspecific competition did differ with locality and depth. Intraspecific encounters were more common in some localities than others (Hornsund > Kongsfjord), and at $6 \mathrm{~m}$ than at $12 \mathrm{~m}$ depth. On comparing the levels of similarity between the

These expected MS are those which would arise with no random sampling variation, but in practice they are obscured by the sampling error. On the null hypothesis of a zero variance component for depth $\left(V_{\mathrm{D}}=0\right)$ the ratio $\mathrm{MS}_{\text {Depth }} / \mathrm{MS}_{\text {error }}$ has an expected value of 1 . In fact, the distribution of this ratio follows an Fdistribution, with 12 and $24 \mathrm{df}$, and this is used to calculate the $\mathrm{p}$-value. The same applies to testing the site variance component, except that in this case we consuites of intraspecific competitors between localities, sites and quadrats, it was clear that localities were quite distinct in both the Arctic and Antarctic (see separation of filled versus open data points in the detrended correspondence analyses in Fig. 3). This technique is usually used for frequency of species but, as can be seen from Fig. 3, can effectively discriminate between communities and scales using the frequency of different types of intraspecific encounters. 
Table 2. Variability in intraspecific competition in Arctic and Antarctic encrusting fauna as a function of scale (2 localities, 3 sites and 2 quadrats, Q)

\begin{tabular}{|c|c|c|c|c|c|c|c|c|c|c|c|c|}
\hline \multirow{3}{*}{ (a) Arctic } & \multicolumn{6}{|c|}{ - Kongsfjord } & \multicolumn{6}{|c|}{-Horsunfiord } \\
\hline & \multicolumn{2}{|c|}{ K1 } & \multicolumn{2}{|c|}{$\mathrm{K} 2$} & \multicolumn{2}{|c|}{ K3 } & \multicolumn{2}{|c|}{ H1 } & \multicolumn{2}{|c|}{$\mathrm{H} 2$} & \multicolumn{2}{|c|}{ H3 } \\
\hline & Q1 & Q2 & Q1 & Q2 & Q1 & Q2 & Q1 & Q2 & Q1 & Q2 & Q1 & Q2 \\
\hline \multicolumn{13}{|l|}{$6 \mathrm{~m}$} \\
\hline \multicolumn{13}{|l|}{$\begin{array}{l}\text { Probability of } \\
\text { intraspecific }\end{array}$} \\
\hline competition & 0.05 & 0.01 & 0.07 & 0.09 & $<0.01$ & 0.01 & 0.11 & 0.05 & 0.10 & 0.07 & 0.04 & 0.07 \\
\hline$\%$ intraspecific & 34.6 & 23.4 & 67.6 & 71.5 & 12.3 & 18.7 & 62.8 & 33.9 & 79.2 & 68.0 & 27.0 & 59.9 \\
\hline$\%$ tied outcomes & 86.7 & 97.9 & 72.0 & 100 & 100 & 100 & 95.3 & 98.4 & 94.3 & 93.6 & 79.5 & 91.9 \\
\hline$\%$ fusion & 0.0 & 0.0 & 0.0 & 0.0 & 0.0 & 0.0 & 0.0 & 0.0 & 0.0 & 0.0 & 0.0 & 0.0 \\
\hline \multicolumn{13}{|l|}{$12 \mathrm{~m}$} \\
\hline \multicolumn{13}{|l|}{$\begin{array}{l}\text { Probability of } \\
\text { intraspecific }\end{array}$} \\
\hline$\%$ intraspecific & 14.3 & 35.8 & 17.1 & 54.9 & 2.8 & 12.7 & 10.8 & 12.6 & 73.2 & 67.2 & 75.0 & 74.1 \\
\hline$\%$ tied outcomes & 100 & 97.3 & 80 & 88.3 & 100 & 80 & 82.8 & 96.0 & 96.8 & 96.3 & 88.1 & 87.2 \\
\hline$\%$ fusion & 0.0 & 0.0 & 0.0 & 0.0 & 0.0 & 0.0 & 0.0 & 0.0 & 0.0 & 0.0 & 0.0 & 0.0 \\
\hline \multirow[t]{3}{*}{ (b) Antarctic } & \multirow{2}{*}{\multicolumn{2}{|c|}{ Billies }} & \multirow{2}{*}{\multicolumn{2}{|c|}{$\begin{array}{c}\text { Signy } \\
\text { Outer Island }\end{array}$}} & & & & & - Ade & aide & & \\
\hline & & & & & \multicolumn{2}{|c|}{ Robin } & \multicolumn{2}{|c|}{ McKay } & \multicolumn{2}{|c|}{ S. Cove } & \multicolumn{2}{|c|}{ Lagoon } \\
\hline & Q1 & Q2 & Q1 & Q2 & Q1 & Q2 & Q1 & Q2 & Q1 & Q2 & Q1 & Q2 \\
\hline \multicolumn{13}{|l|}{$6 \mathrm{~m}$} \\
\hline \multicolumn{13}{|l|}{$\begin{array}{l}\text { Probability of } \\
\text { intraspecific }\end{array}$} \\
\hline $\begin{array}{l}\text { competition } \\
\% \text { intraspecific }\end{array}$ & $\begin{array}{l}0.07 \\
65.9\end{array}$ & $\begin{array}{l}0.06 \\
62.4\end{array}$ & $\begin{array}{l}0.08 \\
59.2\end{array}$ & $\begin{array}{l}0.06 \\
52.7\end{array}$ & $\begin{array}{l}0.07 \\
47.0\end{array}$ & $\begin{array}{l}0.05 \\
50.5\end{array}$ & $\begin{array}{l}0.03 \\
29.8\end{array}$ & $\begin{array}{l}0.04 \\
57.2\end{array}$ & $\begin{array}{l}0.06 \\
62.9\end{array}$ & $\begin{array}{l}0.04 \\
99.2\end{array}$ & $\begin{array}{l}0.06 \\
40.2\end{array}$ & $\begin{array}{l}0.05 \\
57.2\end{array}$ \\
\hline$\%$ tied outcomes & 98.0 & 95.4 & 92.8 & 94.7 & 97.2 & 95.9 & 97.1 & 100 & 94.3 & 98.7 & 96.9 & 100 \\
\hline$\%$ fusion & 0.4 & 0.0 & 0.3 & 0.7 & 0.4 & 0.0 & 0.6 & 0.9 & 0.6 & 0.0 & 0.3 & 0.7 \\
\hline \multicolumn{13}{|l|}{$12 \mathrm{~m}$} \\
\hline \multicolumn{13}{|l|}{$\begin{array}{l}\text { Probability of } \\
\text { intraspecific }\end{array}$} \\
\hline$\%$ intraspecific & 61.5 & 56.7 & 54.3 & 59.8 & 40.9 & 46.1 & 47.4 & 48.7 & 67.1 & 81.9 & 63.7 & 52.6 \\
\hline$\%$ tied outcomes & 93.5 & 94.2 & 95.0 & 90.9 & 93.8 & 95.5 & 97.6 & 95.7 & 97.5 & 98.6 & 98.1 & 97.8 \\
\hline$\%$ fusion & 0.7 & 0.4 & 0.8 & 0.7 & 0.0 & 0.6 & 0.8 & 1.2 & 0.8 & 1.1 & 0.9 & 0.7 \\
\hline
\end{tabular}
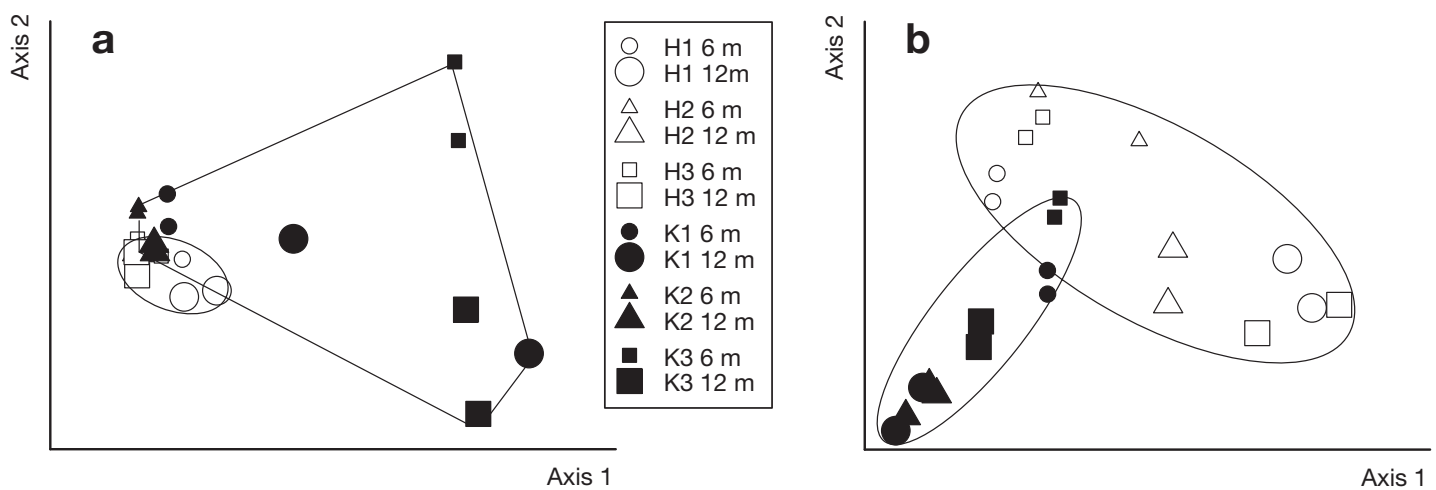

Fig. 3. Detrended correspondence analysis (DCA) of intraspecific competition in (a) Arctic (Barnes \& Kukliński 2004; sites labelled as in Fig. 1) and (b) Antarctic (filled symbols Signy Island, open symbols Adelaide Island) showing similarity between spatial scales and depths. Each data point represents suite of intraspecific interactions in a quadrat. In both (a) and (b), small symbols $=6 \mathrm{~m}$, large symbols $=12 \mathrm{~m}$. Axes do not code for a specific variable in DCA, proximity of points relates to similarity. Eigenvalues associated with axes are 0.87 and 0.14 (a), 0.65 and 0.09 (b). Further axes contributed little to explaining data 
Table 3. Analysis of 3 different measures of importance of intraspecific competition: (a) probability of competition occurring, (b) proportion of competitive encounters that are intraspecific rather than interspecific and (c) outcomes of competition (proportion of ties rather than wins or losses). All analyses are fully nested ANOVAs (random-effects model) with output presented in standard form. Significance is shown at $<0.05\left({ }^{*}\right)$ and $<0.01\left({ }^{* *}\right)$ levels. All response data were arcsine-transformed. Summary of spatial factors influencing (a) probability of bryozoan colonies being involved in intraspecific competition, (b) proportion of bryozoans intraspecific (cf. interspecific) competition, and (c) proportion of tied outcomes in bryozoan intraspecific (cf. interspecific) competition. Note $\mathrm{MS}_{\text {Site }} / \mathrm{MS}_{\text {Depth }}$ is significant ( $\mathrm{p}=0.045$ ) (but if $\mathrm{MS}_{\mathrm{Site}} / \mathrm{MS}_{\text {error }}$ is used as denominator $\mathrm{p}=0.21$ ). Thus, statistical significance is due to the relatively low value of $\mathrm{MS}_{\text {Depth }}$ (actually less than $\mathrm{MS}_{\text {error }}$ )

\begin{tabular}{|c|c|c|c|c|c|c|c|}
\hline & Source & $\mathrm{df}$ & SS & MS & $F$ & $\mathrm{p}$ & $\begin{array}{c}\% \text { total } \\
\text { variance }\end{array}$ \\
\hline \multirow[t]{6}{*}{ (a) } & Region & 1 & 0.0003 & 0.0003 & 0.056 & 0.835 & 0.0 \\
\hline & Locality & 2 & 0.0107 & 0.0053 & 6.163 & $0.024^{*}$ & 31.6 \\
\hline & Site & 8 & 0.0069 & 0.0009 & 0.636 & 0.735 & 0.0 \\
\hline & Depth & 12 & 0.0164 & 0.0014 & 5.450 & $0.000^{* *}$ & 47.2 \\
\hline & Error & 24 & 0.0060 & 0.0002 & & & 21.2 \\
\hline & Total & 47 & 0.0403 & & & & \\
\hline \multirow[t]{6}{*}{ (b) } & Region & 1 & 2632.9219 & 2632.9219 & 1.582 & 0.335 & 7.5 \\
\hline & Locality & 2 & 3328.1171 & 1664.0585 & 1.349 & 0.313 & 6.7 \\
\hline & Site & 8 & 9870.1633 & 1233.7704 & 3.969 & $0.016^{*}$ & 43.0 \\
\hline & Depth & 12 & 3730.4425 & 310.8702 & 2.101 & 0.059 & 15.2 \\
\hline & Error & 24 & 3551.1450 & 147.9644 & & & 27.6 \\
\hline & Total & 47 & 23112.7898 & & & & \\
\hline \multirow[t]{6}{*}{ (c) } & Region & 1 & 237.6300 & 237.6300 & 9.073 & 0.095 & 15.9 \\
\hline & Locality & 2 & 52.3817 & 26.1908 & 0.467 & 0.643 & 0.0 \\
\hline & Site & 8 & 448.9800 & 56.1225 & 2.948 & $0.045^{*}$ & 16.7 \\
\hline & Depth & 12 & 228.4450 & 19.0371 & 0.508 & 0.889 & 0.0 \\
\hline & Error & 24 & 899.6600 & 37.4858 & & & 67.4 \\
\hline & Total & 47 & 1867.0967 & & & & \\
\hline
\end{tabular}

\section{Proportion of intraspecific competition}

The proportion of encounters that were intraspecific (compared to interspecific) varied considerably within both the Arctic and Antarctic study regions. This aspect, more than any other considered in this study, illustrated just how patchy the nearshore shallow polar environment is. In West Spitsbergen, $6 \mathrm{~m}$ sample communities could be dominated ( $>79 \%$ ) by intraspecific encounters or they could constitute little more than $12 \%$ of meetings (Table 2). Likewise, for sample communities at Signy and Adelaide Islands, the proportion of spatial encounters which were intraspecific varied from $\sim 30$ to $99 \%$. The mean level at the 4 latitudes studied was comparatively high (Fig. 4), but individual site values spanned almost the global range reported. Significant variability was confined to the smallest spatial scale considered here, i.e. site (Table 3b). This massive variability at the scale of sub-kilometres provides a context to the interpretation of large global patterns (Fig. 4) and emphasises just how important sampling within latitude is.
To further elucidate the high variability in the proportion of spatial intraspecific competition, the data were examined as a function of species. The range of values found was even greater than the overall spatial range. Intraspecific encounters comprised between 5 and $84 \%$ of encounters in different Antarctic species (Table 4) although, within any one species, variability was low (low SEs). This variability between species was highly significant (ANOVA, df 9, $F=5.58$, $\mathrm{p}<0.01)$. Although the interactions involving most species were not with conspecifics (i.e. they were interspecific), the encounters of a few species were mostly intraspecific. The highest proportion of intraspecific competition was generally found in those species at the extremes of competitive ability, i.e. very poor competitors or (less commonly) very good competitors (Fig. 5). This pattern was evident in both polar regions and at all 4 localities, although only at Signy Island was the highest proportion of intraspecific competition attributable to a very good competitor. Thus, pioneer species and a few of the top competitors were highly likely to meet conspecifics, whilst species with average competitive performance rarely met conspecifics.

\section{Proportion of intraspecific competition resulting in tied outcomes}

Most intraspecific competition resulted in tied outcomes (Table 2). However, in contrast to the proportion of competition which was intraspecific, this varied little. In Arctic Spitsbergen, values ranged from 72 to $100 \%$, and in the Scotia Arc/Antarctic Peninsula regions, variability was just 92.8 to $100 \%$. We did not, however, find region to be a significant factor explaining variability in the proportion of intraspecific encounters leading to tied outcomes. Only site emerged as significant in terms of influence on the levels of tied outcomes amongst the spatial scales investigated (Table 3b).

Between sites, the range of intraspecific competition resulting in tied outcomes in whole assemblages was small. Between species, however, the range of values was high (10 to 99\% in Antarctic species: Table 4); 2 features of species, their overgrowth ability (performance in interspecific competition) and potential for bilaminar 
Table 4. Mean (+ $\mathrm{SE} ; 5$ replicate samples), prevalence of competition, intraspecific interactions, tied outcomes and fusion (homosyndrome) in intraspecific interactions for 10 species of Antarctic bryozoans at 2 localities (Signy Island and Adelaide Island). Data are proportions (1.0 $=100 \%$ of colonies). Min. $\mathrm{n}$ : minimum number of colonies constituting each sample; nd: no data

\begin{tabular}{|c|c|c|c|c|c|}
\hline Location & Competition & Intraspecific & Tied & Fusion & Min. $\mathrm{n}$ \\
\hline \multicolumn{6}{|c|}{ Arachnopusia inchoata } \\
\hline Signy & $0.89(0.04)$ & $0.12(0.03)$ & $0.18(0.01)$ & 0 & 957 \\
\hline Adelaide & $0.75(0.07)$ & $0.16(0.01)$ & $0.1(0.01)$ & 0 & 435 \\
\hline \multicolumn{6}{|c|}{ Amphiblestrum familiaris } \\
\hline Signy & $0.84(0.05)$ & $0.09(0.01)$ & $0.61(0.05)$ & 0 & 452 \\
\hline Adelaide & nd & nd & nd & nd & nd \\
\hline \multicolumn{6}{|c|}{ Beania erecta } \\
\hline Signy & $0.99(0.01)$ & $0.24(0.01)$ & $0.30(0.06)$ & 0 & 180 \\
\hline Adelaide & $0.97(0.01)$ & $0.61(0.02)$ & $0.21(0.04)$ & 0 & 166 \\
\hline \multicolumn{6}{|c|}{ Celleporella bougainvillei } \\
\hline Signy & $0.35(0.06)$ & $0.12(0.02)$ & $0.43(0.03)$ & 0 & 1723 \\
\hline Adelaide & $0.63(0.05)$ & $0.11(0.01)$ & $0.54(0.06)$ & 0 & 290 \\
\hline \multicolumn{6}{|c|}{ Ellisina Antarctica } \\
\hline Signy & $0.67(0.06)$ & $0.07(0.01)$ & $0.35(0.03)$ & 0 & 1127 \\
\hline Adelaide & $0.66(0.03)$ & $0.05(0.01)$ & $0.46(0.03)$ & 0 & 190 \\
\hline \multicolumn{6}{|c|}{ Escharoides tridens } \\
\hline Signy & $0.61(0.03)$ & $0.10(0.03)$ & $0.59(0.05)$ & 0 & 1654 \\
\hline Adelaide & $0.66(0.03)$ & $0.26(0.02)$ & $0.59(0.06)$ & 0 & 520 \\
\hline \multicolumn{6}{|c|}{ Fenestrulina rugula } \\
\hline Signy & $0.75(0.02)$ & $0.19(0.01)$ & $0.94(0.02)$ & $0.10(0.01)$ & 733 \\
\hline Adelaide & $0.70(0.07)$ & $0.84(0.02)$ & $0.99(0.01)$ & $0.07(0.02)$ & 750 \\
\hline \multicolumn{6}{|c|}{ Inversiula nutrix } \\
\hline Signy & $0.57(0.03)$ & $0.17(0.03)$ & $0.86(0.03)$ & 0 & 1839 \\
\hline Adelaide & $0.51(0.03)$ & $0.54(0.03)$ & $0.84(0.03)$ & 0 & 702 \\
\hline \multicolumn{6}{|c|}{ Micropora brevissima } \\
\hline Signy & $0.81(0.04)$ & $0.09(0.03)$ & $0.70(0.07)$ & 0 & 1088 \\
\hline Adelaide & $0.72(0.02)$ & $0.11(0.01)$ & $0.35(0.02)$ & $0.01(0.01)$ & 408 \\
\hline \multicolumn{6}{|c|}{ Microporella stenoporta } \\
\hline Signy & $0.85(0.04)$ & $0.14(0.01)$ & $0.89(0.01)$ & $0.09(0.02)$ & 488 \\
\hline Adelaide & $0.66(0.04)$ & $0.20(0.03)$ & $0.90(0.02)$ & $0.06(0.02)$ & 379 \\
\hline \multicolumn{6}{|c|}{ Valdemunitella lata } \\
\hline Signy & $0.99(0.01)$ & $0.10(0.01)$ & $0.33(0.06)$ & 0 & 183 \\
\hline Adelaide & nd & nd & nd & nd & nd \\
\hline
\end{tabular}

foliaceous growth (growth form), were found to have strong correlations with the type of outcomes in intraspecific encounters. There was a simple linear relationship between performance in interspecific competition (wins/total encounters) and the likelihood of tied outcomes in intraspecific competition (Fig. 6), i.e. intraspecific interactions in highly ranked species (those which won most encounters with other species) rarely resulted in tied outcomes. In contrast, intraspecific interactions within pioneer species (which were usually overgrown by any other competitor species they encountered), mostly ended up in ties (stand-offs).

Species with the potential for bilaminar foliaceous growth forms, such as Arachnopusia incoata in the Antarctic or Cheilopora prealucida in the Arctic, had an alternative outcome to many intraspecific encounters. This outcome could be regarded as a tie, but we considered it an alternative outcome to either a win/loss or tie. When encrusting zooids met others, either of the same colony or other conspecifics, they grew such that the undersurface (base) of each colony grows against the other base using it as a substratum. The result was large, multiple-folded, 3D 'foliaceous' structures that were up to $2 \times 1 \mathrm{~m}$ in size (in Antarctica; these were considerably smaller in the Arctic). This type of interaction and the form generated comprised 1 of 2 types of 'constructive' encounters, with the other involving an even closer linkage, i.e. fusion.
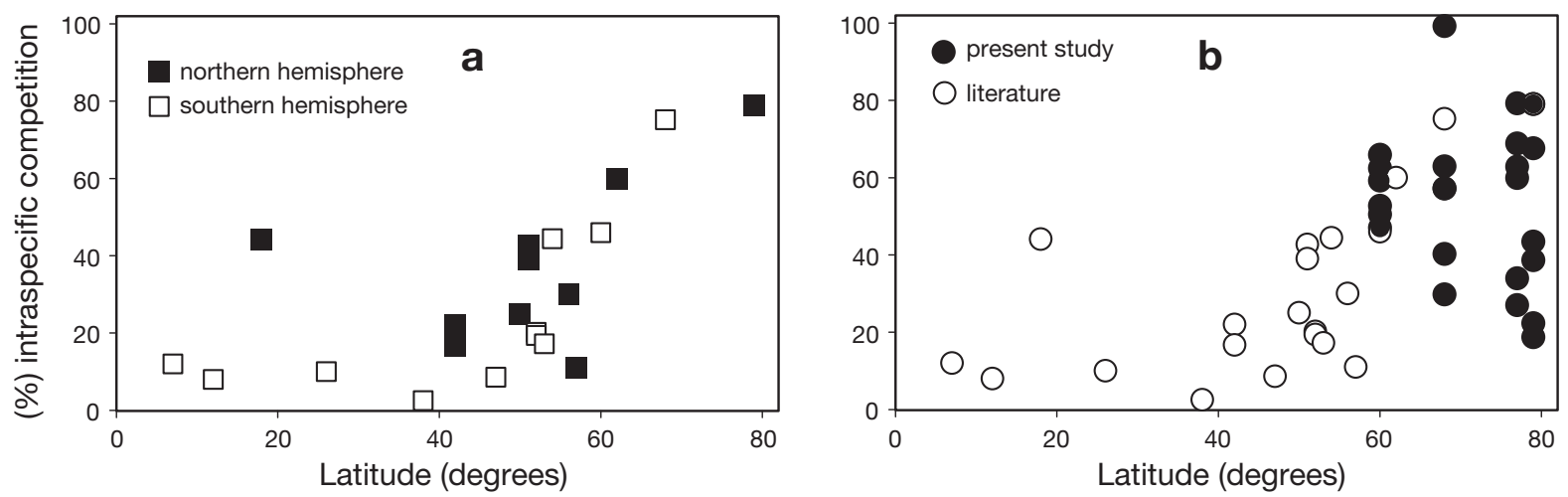

Fig. 4. Competition structure as a function of latitude. (a) Intraspecific proportion of competition in southern and northern hemispheres; data from the literature (Barnes \& Kukliński 2003 and references therein). (b) Variability in values from the present study compared with variability in combined literature data 


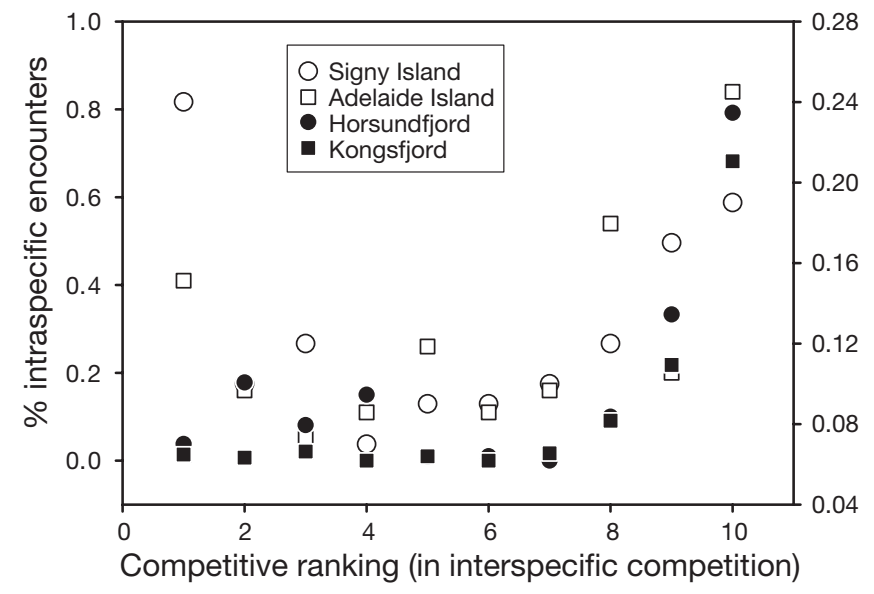

Fig. 5. Proportion of intraspecific competitive encounters in Arctic (filled symbols) and Antarctic (open symbols) localities as a function of competitive ranking. Data for Signy Island are scaled on right (offset) $y$-axis, all other data are scaled on left $y$-axis

\section{Proportion of intraspecific competition resulting in homosyndrome fusion}

No intraspecific encounters between different colonies resulted in fusion (homosyndome) in any of the 5 investigated Arctic species (Cribrilina annulata, Electra arctica, Harmeria scutulata, Tegella arctica, and $T$. retroversa). Of the 11 Antarctic species investigated, homosyndrome between colonies occurred in 3 (Fenestrulina rugula, Micropora brevissima and Microporella stenoporta: Table 4); in M. brevissima, however, homosyndrome occurred on just 1 occasion. Therefore, the phenomenon of homosyndrome was not common in polar regions and not present at all in Arctic species

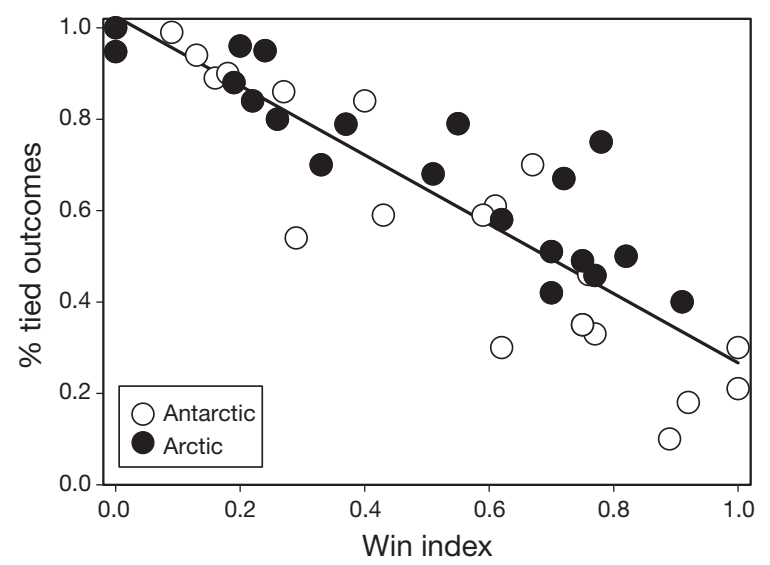

Fig. 6. Proportion of intraspecific competitive encounters resulting in tied outcomes for Arctic and Antarctic localities as a function of win index (species performance in spatial competition). Relationship shown explains $\left(\mathrm{r}^{2}\right) 80.9 \%$ of variability and is significant (ANOVA, df $1, F=100.8, \mathrm{p}<0.001$ ) studied. In 2 Antarctic species, however, homosyndrome was the outcome of between 6 and $10 \%$ of intraspecific meetings between colonies. Given sample sizes of hundreds of interactions for each species, we would suggest on the basis of these results that, for whatever reason, homosyndrome seems to be more likely in some species than others and in one polar region than the other.

We found that colonies that had fused zooids in Fenestrulina rugula, the species for which we had most observations, displayed high reproductive investment (proportion of zooids brooding embryos). The proportion of zooids showing reproductive activity increased with increasing colony size (Fig. 7). Compared to colonies encountering no other colonies, those involved in interspecific and intraspecific interactions had double and triple the number of zooids with ovicells in, respectively (Fig. 7). The only colonies ( $<200$ zooids in size) having $>30 \%$ zooids with ovicells were those which had fused with another colony.

\section{DISCUSSION}

This study has focused on competition between encrusters of marine boulders. Coastal boulders are common habitats along rugged, ice-scraped polar coastlines and often seem denuded of fauna. However, the undersurfaces of such boulders, are often crowded by macrofauna, mainly pioneers, competing for space (Barnes 2000, Barnes \& Kukliński 2003). Being amongst the most disturbed habitats in the world (Arntz et al. 1994, Gutt \& Pipenburg 2003), they provide a natural end-point to concepts such as the intermediate disturbance hypothesis (Connell 1978, Huston 1979). Our

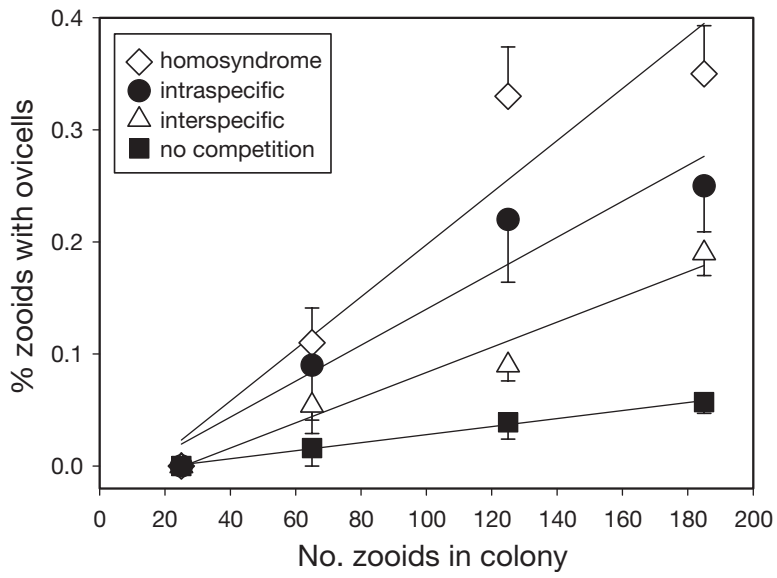

Fig. 7. Antarctic bryozoan Fenestrulina rugula. Reproductive strategy as a function of colony size and enounter type: none, interspecific, intraspecific with no fusion, and fusion (homosyndrome) with conspecifics. All linear relationships shown have $\mathrm{r}^{2}>34 \%$ and are significant (ANOVA on arcsinetransformed data, df $1, F>14.8, \mathrm{p}<0.01)$ 
first hypothesis concerned the prevalence and outcomes of intraspecific encounters. The spatially nested design we used to test this in West Spitsbergen and West Antarctica did show significant variance in the importance of intraspecific competition in space, but at a local rather than a regional scale.
Table 5. Likely relationship between disturbance, species diversity and frequency of intraspecific encounter, in polar, nearshore, marine environments

\begin{tabular}{|llc|}
\hline Disturbance & \multicolumn{1}{c|}{ Diversity } & $\begin{array}{c}\text { Encounter } \\
\text { frequency }\end{array}$ \\
\hline High or recent & Low; mainly 1 or 2 pioneers & High \\
Moderate or $\sim$ decade ago & High; range of many lithophiles & Low \\
Low or many decades ago & Low; mainly 1 or 2 dominants & High \\
\hline
\end{tabular}

\section{Frequencies of intraspecific competition (Hypothesis 1)}

As reported here for polar benthic habitats, in certain environments and organisms, intraspecific meetings dominate competition for space. This happens when communities and large areas of space are dominated by just a few species, such as barnacles or mussels on temperate shores (Connell 1961, Dayton 1971, Paine 1974). The same can happen in the subtidal (Karlson 1983, 1999), particularly at high polar latitudes where just 1 or 2 pioneer species may be highly abundant in patches (Barnes \& Clarke 1998, Barnes \& Kukliński 2003, and present study). We found that the frequency of intraspecific competition was insignificantly different between our Arctic and Antarctic study areas (Table 3a). Similarly, we found that the proportion of competition that was intraspecific (compared to interspecific) did not differ between the northern and southern polar regions (Table 3b). We did, however, find significant differences at smaller scales within each polar region, and important largescale patterns in intraspecific competition within each polar region. Most spatial competition on boulders is intraspecific in polar nearshore assemblages, whereas at lower latitudes it is mostly interspecific (Fig. 4). In temperate and tropical waters the proportion of interactions that are intraspecific is approximately $30 \%$, whereas above $60^{\circ} \mathrm{N}$ or $60^{\circ} \mathrm{S}$ it is about $60 \%$. Given these large-scale patterns from tropics to poles, why have we found most variability in polar regions at small spatial scales?

We suggest the key factor is ice disturbance, which is typically important in polar communities (Conlan et al. 1998, Gutt 2001, Gutt \& Pipenburg 2003). In common with theory and results from deeper-water studies (Dayton 1990, Gutt et al. 1996), we suggest that ice probably affects similar assemblages in similar ways in both polar regions. Thus, encounters between pioneers differ little overall between north and south. We suspect that the significant smaller-scale effects we found within each polar region reflect the patchiness of ice scour: in places where ice has recently scoured, little colonisation occurs, interactions should be rare, and pioneers should be most abundant, so that most of the few encounters are intraspecific (Table 5, Fig. 8a).

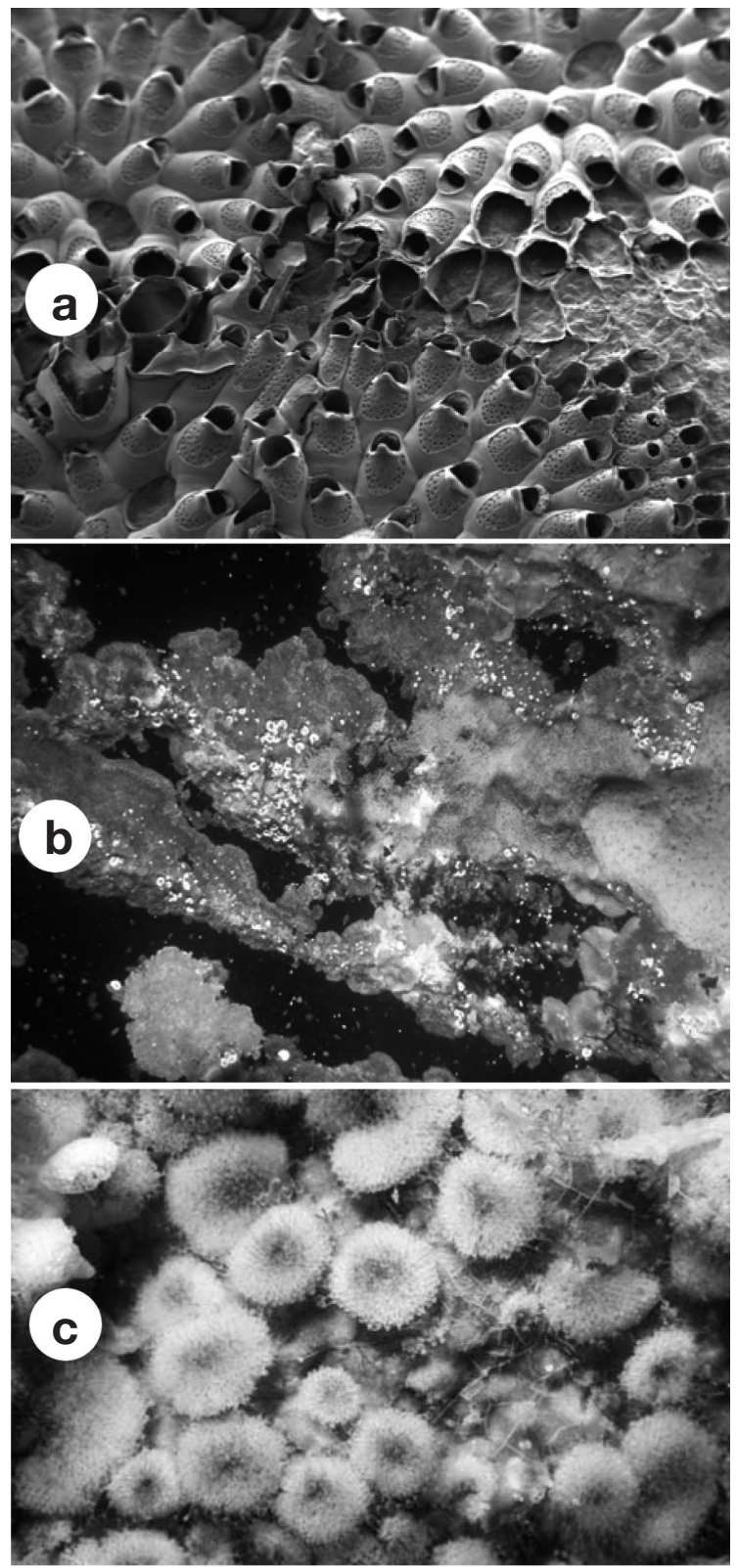

Fig. 8. Assemblage development at various time points. (a) 1 yr old; space mainly occupied by single pioneer species such as Harmeria scutulata in Arctic, (b) <6 yr old; variety of species, competition for space between conspecifics, different species, families, orders, classes and phyla present, (c) $>10 \mathrm{yr}$ old; space mainly occupied by few overgrowth dominants such as Beania erecta in Antarctic 
In moderately scoured or assemblages scoured years earlier, many species are likely to be present, so interspecific rather than intraspecific encounters should be abundant (Fig. 8b). In rarely scoured (ice-protected) assemblages, species dominating the overgrowth monopolise space (Barnes 2002), so intraspecific encounters between these species are abundant (Fig. 8c). Thus, at either end of the spectrum, intraspecific interactions are the most common type, albeit of differing density, as would be expected when applying the intermediate disturbance hypothesis (Connell 1978, Huston 1979).

The probability of intraspecific interaction occurring ranged from $<1$ to $11 \%$, varying significantly with locality (within each polar region) and depth. We interpret a 1 to $11 \%$ chance of involvement in (intraspecific) spatial interactions as low. Perhaps surprisingly, given the vast bulk of work on competition between species, we could find no comparable values in the ecological literature to indicate how often competition for resources occurs in other species at other places. Competition between individuals of the same species of barnacles (for space see Connell 1961) and hermit crabs (for shells see Hazlett 1981) is highly likely. It might also seem reasonable to suppose that many species in low-latitude habitats such as coral reefs, mangroves or rain forests (Connell 1978, Karlson 1999) are likely to experience spatial competition from conspecifics. Is there evidence for latitudinal (or longitudinal) differences in the intensity of competition? As often appears to be the case, there seems to be more discussion, theory or explanation of large-scale patterns (see Clarke 1992, Rhode 1995, Gray 2001, Allen et al. 2002) than actual comparative data (but see Stehli \& Wells 1971, Roy et al. 1998, Clarke \& Lidgard 2000, Crame 2000).

\section{Nature of outcomes of intraspecific competition}

The outcomes of competitive encounters change with many variables, such as relatedness of competitors (Diamond 1987, Barnes 2003), taxonomic membership of competitors (Tanaka \& Nandakumar 1994) and latitude (Barnes 2002). We found that ties (stand-offs) were by far the most common outcome in polar intraspecific meetings. Ties accounted for $>90 \%$ in both Antarctic localities (Table 2), but have also been reported as very common in some temperate ascidian (Schmidt \& Warner 1986) and bryozoan (Stebbing 1973) assemblages. We did not find any significant difference between the frequency of ties in the 2 polar regions (Table 3c). Only at the scale of kilometres (site) did we find a (just) significant effect. This was probably due to different species involved at a scale where species distributions are highly patchy. At a larger scale, equivalent assemblages (shallow-water encrusting fauna) at non-polar latitudes have been found to have fewer tied outcomes (Barnes 2000).

We found that many intraspecific encounters resulted in constructive outcomes, as has been reported in some other situations (Karlson 1980). These included bryozoans growing against each other to become bilaminar and erect, forming large foliaceous colonies $\left(>1 \mathrm{~m}^{3}\right)$ or bioconstructions (Cocito et al. 2000). We found that foliaceous growth usually resulted from intraspecific interactions between bilaminar species, at both polar regions. Thus, the frequency and outcomes of intraspecific encounters are highly connected with localscale biodiversity, as these foliaceous bioconstructions may harbour tens of species in temperate (Cocito et al. 2000) and polar (D. K. A. Barnes pers. obs.) seas.

\section{Species identity and prevalence/outcomes of intraspecific interactions (Hypothesis 2)}

Our second hypothesis concerned the prevalence and outcomes of bryozoan intraspecific encounters among species. We found a strong link between the competitive nature of species and their likelihood of being involved in intra- versus interspecific competition (Fig. 5). Pioneers (e.g. Harmeria scutulata, Fig. 8a) were mostly involved in intraspecific interactions, as were some of the stronger overgrowth dominants (e.g. Beania erecta, Fig. 8c). Mid-strength (mid-successional) species mainly encountered other species rather than conspecifics, suggesting assemblages to be diverse at this stage (Fig. 8b). Clearly species in high-latitude nearshore assemblages do not have equal likelihoods of meeting other species. Furthermore, the outcomes of intraspecific competition changed considerably with the competitive nature of the species (Fig. 6). Interactions within pioneer species mostly resulted in tied outcomes. Such outcomes were rare in intraspecific encounters between stronger overgrowth dominants, while mid-strength (mid-successional) species were intermediate - neither ties nor decided outcomes were more common. We can therefore reject our hypothesis: the identity of species has a very important influence on the outcome of even intraspecific competition. Species identity was an important factor to an entirely different outcome of intraspecific encounters, i.e. homosyndrome (fusion).

\section{Homosyndrome}

Between-colony fusion (homosyndrome) is worthy of note, as only in patterns of this did we find marked Arctic-Antarctic differences involving intraspecific 
competition. Fusion only occurred in 2 (on 1 occasion in a third) of 11 Antarctic species (Table 4), and only 5 Arctic species were investigated, so we cannot claim to have found any strong basis to suggest between-polar differences. Homosyndrome is known for a few temperate bryozoans (Knight-Jones \& Moyse 1961, Craig 1994, Manríquez 1999, Craig \& Wasson 2000), ascidians (Sabbadin 1962) and hydroids (Grosberg et al. 1996), and a polar bryozoan (Barnes \& Clarke 1998). As only closely related colonies are intuitively likely to fuse, any differences between the rates of a species homosyndrome may simply reflect the dispersal potential of that species. Our study species probably have in most cases lecithotrophic coronate larvae, but the duration of larval life may vary between species. Even if this were not so, but the timing of larval release differed, transport opportunities could differ substantially according to whether larvae are released into calm, winter, water under-ice or rough, summer, open-sea conditions. The fact that homosyndrome occurs commonly in the most prominent Antarctic pioneer and a virtually equivalent temperate species (Manríquez 1999) and yet has not been found in equivalent Arctic pioneers makes the phenonomenon worthy of closer investigation. Homosyndrome also seems to be a powerful agent for hastening the onset of sexual activity/production of larvae (Fig. 7), probably due to stress (Hughes et al. 2003); yet our data (Fig. 7) indicates that reproductive activity is accelerated faster by homosyndrome than by interspecific interactions. If stress is causative, as is known in at least 1 bryozoan (Hughes et al. 2003), it seems intuitively strange that homosyndrome should have a more severe effect than interspecific encounters - which almost certainly result in pioneers being completely overgrown (Barnes 2002). An alternative explanation is that the instantaneous increase in colony size caused by homosyndrome takes the colony above the size threshold for reproduction.

\section{Signals and implications of climate warming and conclusions}

Our findings suggest that polar patterns of intraspecific competition could be used as a powerful signal of the extent of biological response to polar oceanwarming and glacier collapses; yet even recently, competition on polar shores was assumed to be ecologically irrelevant, with the 'denuded' appearance of polar shores leading ecologists to conclude that space was not limiting (Connell 1985, Roughgarden 1986, Menge \& Sutherland 1987). Were they right? Our data show that up to $11 \%$ of bryozoan colonies experienced intraspecific competition at any one site, but typical val- ues were considerably lower (Table 2). Thus, intraspecific competition is common but ice scour is so frequent relative to the pace of recolonisation that shallow-water assemblages remain mostly as unimpeded pioneer species (Gutt et al. 1996, Barnes \& Clarke 1998, Conlan et al. 1998, Gutt 2001, Barnes \& Kukliński 2003). Nevertheless there are 3 reasons why spatial interactions in these young assemblages are ecologically important. Firstly, assemblages can be identified at all scales on the basis of their pattern of intraspecific interactions (Fig. 3). Secondly, the prevalence and outcomes of intraspecific competition in both polar regions demonstrably differ from patterns at other latitudes (Fig. 4). Thirdly, and of most importance, patterns of intraspecific competition are a simple surrogate measure for marine assemblage diversity and should also be so for community responses to climate change.

The climate of the Arctic is changing rapidly, but the Arctic environment is and has been characterised by rapid changes over various scales in time (Dayton 1990, Loeng 1991, Quadfasel et al. 1991). Sea-temperature rises predicted by the Hadley Centre Model 3 (Murphy \& Mitchell 1995) may have major thermal implications for the functional capability of many Antarctic marine animals (Peck 1998, 2002, Pörtner et al. 1999, 2002a,b), but possibly not for those in the Arctic. However icesheet collapses due to warming should change the iceloading of waters in both regions (Doake \& Vaughan 1991) and thus dramatically change the disturbance regime. If disturbance regimes do temporarily increase because there is more floating ice in the nearshore environment, we predict decreased patchiness, and increased abundance of pioneers and intraspecific competition. In the medium term (but probably within our lifetimes), with disappearing ice in the Arctic we can predict a temporary increase in patchiness, diversity and interspecific competition with decreasing levels of disturbance. However, ultimately, species like Tegella retroversa and various ascidians are likely to occupy all available space, causing diversity to decline and intraspecific competition to predominate in encrusting Arctic assemblages. Monitoring the northern polar nearshore benthos may comprise a large-scale test of the intermediate disturbance hypothesis (Connell 1978, Huston 1979). Measuring pairwise encounters in cryptic fauna is fairly small-scale, yet it has demonstrated that variability occurs at the scale of kilometres rather than thousands of kilometres. We suggest that measuring such interactions in the future will give powerful insight into massive but differential changes in the 2 polar regions.

Acknowledgements. The authors wish to thank all the scientific staff and crew of the Polish Academy of Sciences RV 'Oceania'. We are also very grateful to Jan Marcin Węsławski 
for the invitation to D.K.A.B. to join the 2002 West Spitsbergen cruise of 'Oceania'. The study was completed thanks to the funds provided to P.K. through a grant from the European Commission's programme 'Transnational Access to Major Research Infrastructures' to COBICE, Zoological Museum in Copenhagen. Finally we thank Professor Lloyd Peck and 4 anonymous referees for comments leading to a much improved manuscript.

\section{LITERATURE CITED}

Allen AP, Brown JH, Gillooly JF (2002) Global biodiversity, biochemical kinetics, and the energetic-equivalence rule. Science 297:1545-1548

Arntz WE, Brey T, Gallardo VA (1994) Antarctic zoobenthos. Oceanogr Mar Biol Annu Rev 32:251-303

Barnes DKA (2000) Diversity, recruitment and competition on island shores at polar locations compared with lower latitudes; encrusting community examples. Hydrobiologia 440:37-44

Barnes DKA (2002) Polarization of competition increases with latitude. Proc R Soc Lond Ser B 269:2061-2069

Barnes DKA (2003) Competition asymmetry with taxonomic divergence. Proc R Soc Lond Ser B 270:557-562

Barnes DKA, Brockington S (2003) Zoobenthic biodiversity, biomass and abundance at Adelaide Island, Antarctica. Mar Ecol Prog Ser 249:145-155

Barnes DKA, Clarke A (1998) The ecology of an assemblage dominant: the encrusting bryozoan Fenestrulina rugula. Invertebr Biol 117:331-340

Barnes DKA, Kukliński P (2003) High polar spatial competition: extreme hierarchies at extreme latitude. Mar Ecol Prog Ser 259:17-28

Barnes DKA, Kukliński P (2004) Variability of competition at $10^{1}, 10^{3}, 10^{5}$, and $10^{6} \mathrm{~m}$ scales: encrusting arctic community patterns. Mar Biol 145:351-372

Bell JJ, Barnes DKA (2004) The importance of competitor identity, morphology and ranking methodology to outcomes in interference competition in sponges. Mar Biol 143:415-426

Buss LW, Jackson JBC (1979) Competitive networks: nontransitive competitive relationships in cryptic coral reef environments. Am Nat 113:223-234

Chornesky EA (1989) Repeated reversals during spatial competition between corals. Ecology 70:843-855

Clarke A (1992) Is there a latitudinal diversity cline in the sea? Trends Ecol Evol 7:286-287

Clarke A, Lidgard S (2000) Spatial patterns of diversity in the sea: bryozoan species richness in the North Atlantic. J Anim Ecol 69:799-814

Clarke A, Holmes LJ, White MG (1988) The annual cycle of temperature, chlorophyll and major nutrients at Signy Island, South Orkney Islands, 1969-82. Br Antarct Surv Bull 80:65-86

Clutton-Brock TH, Albon SD, Gibson RM, Guiness FE (1979) The logical stag: adaptive aspects of fighting in red deer (Cervus elaphus L.). Anim Behav 27:211-225

Cocito S, Ferdeghini F, Morri C, Bianchi NC (2000) Patterns of bioconstruction in the cheilostome bryozoan Schizoporella errata: the influence of hydrodynamics and associated biota. Mar Ecol Prog Ser 192:153-161

Conlan KE, Lenihan HS, Kvitek RG, Oliver JS (1998) Ice scour disturbance to benthic communities in the Canadian high Arctic. Mar Ecol Prog Ser 166:1-16

Connell JH (1961) The influence of interspecific competition and other factors on the distribution of the barnacles Chthamalus stellatus. Ecology 42:710-723
Connell JH (1978) Diversity in tropical rain forests and coral reefs. Science 199:1302-1310

Connell JH (1985) Variation and persistence of rocky shore populations. In: Moore PG, Seed R (eds) The ecology of rocky coasts. Hodder \& Stoughton, London, p 57-69

Craig $S$ (1994) Intraspecific fusion in the encrusting bryozoan Fenestrulina sp. In: Hayward P, Ryland JS, Taylor PD (eds) Biology and palaeobiology of bryozoans. Olsen \& Olsen, Fredensborg, p 51-55

Craig F, Wasson K (2000) Self/non-self recognition and fusion in the bryozoan Hippodiplosia insculpta. In: Herrera $\mathrm{Cu}-$ billa A, Jackson BC (eds) Proceedings of the 11th International Bryozoology Association Conference. Smithsonian Tropical Research Institute, Balboa, p 89-196

Crame JA (2000) Evolution of taxonomic diversity gradients in the marine realm: evidence from the composition of recent bivalve faunas. Paleobiology 26:188-214

Darwin C (1859) On the origin of species. Murray, London

Dayton PK (1971) Competition, disturbance and community organisation: the provision and subsequent utilisation of space in a rocky intertidal community. Ecol Monogr 41: 351-389

Dayton PK (1990) Polar benthos. In: Smith WO (ed) Polar oceanography. Academic Press, London, p 631-685

Diamond JM (1987) Competition among different taxa. Nature 326:241

Doake CSM, Vaughan DG (1991) Rapid disintegration of the Wordie ice shelf in response to atmospheric warming. Nature 350:328-330

Gray JS (2001) Marine diversity: the paradigms in patterns of species richness examined. Sci Mar 65:41-56

Grosberg RK, Levitan DR, Cameron BB (1996) Evolutionary genetics of allorecognition in the colonial hydroid Hyractinia symbiologicarpus. Evolution 50:2221-2240

Gutt J (2001) On the direct impact of ice on marine benthic communities, a review Polar Biol 24:553-564

Gutt J, Pipenburg D (2003) Scale dependent impact on diversity of Antarctic benthos caused by grounding of icebergs. Mar Ecol Prog Ser 253:77-83

Gutt J, Starmans A, Dieckmann G (1996) Impact of iceberg scouring on polar benthic habitats. Mar Ecol Prog Ser 137: 311-316

Hazlett BA (1981) The behavioural ecology of hermit crabs. Annu Rev Ecol Syst 12:1-22

Hughes RN, Manríquez PH, Bishop JDD, Burrows MT (2003) Stress promotes maleness in hermaphroditic modular animals. Proc Natl Acad Sci USA 100:10326-10330

Huston M (1979) A general hypothesis of species diversity. Am Nat 113:81-101

Jackson JBC, Buss L (1975) Allelopathy and spatial competition among coral reef invertebrates. Proc Natl Acad Sci USA 72:5160-5163

Karlson RH (1980) Alternative competitive strategies in a periodically disturbed habitat. Bull Mar Sci 30:894-900

Karlson RH (1983) Disturbance and monopolisation of a spatial resource by Zooanthus sociatus. Bull Mar Sci 33: 118-131

Karlson RH (1999) Dynamics of coral communities. Kluwer Academic, Dordrecht

Knight-Jones EW, Moyse J (1961) Intraspecific competition in sedentary marine animals. Symp Soc Exp Biol 15:72-95

Loeng $H$ (1991) Features of the physical, oceanographic conditions of the Barents Sea. Polar Res 10:5-18

Manríquez PH (1999) Mate choice and reproductive investment in the cheilostome bryozoan Celleporella hyalina. $\mathrm{PhD}$ thesis, University of Wales, Bangor

McKinney FK (1995) One hundred million years of competi- 
tive interactions between bryozoan clades: asymmetrical but not escalating. Biol J Linn Soc 56:465-481

Menge BA, Sutherland JP (1987) Community regulation: variation in disturbance, competition and predation in relation to environmental stress and recruitment. Am Nat 130: $730-757$

Murphy JM, Mitchell JFB (1995) Transient response of the Hadley Centre coupled ocean-atmosphere model to increasing carbon dioxide. J Climate 8:57-80

Paine RT (1974) Intertidal community structure: experimental studies on the relationship between a dominant competitor and its principal preditor. Oecologia 15:710-719

Peck LS (1998) Feeding, metabolism and metabolic scope in Antarctic marine ectotherms. Soc Exp Biol Semin Ser 66: 365-390

Peck LS (2002) Ecophysiology of Antarctic marine ectotherms: limits to life. Keynote contribution, Antarctic Treaty Organisation Scientific Committee on Antarctic Research, Ecology of the Antarctic Sea Ice Zone, Bremerhaven, June 1999. Polar Biol 25:31-40

Pörtner HO (2002a) Climate variations and the physiological basis of temperature-dependent biogeography: systematic to molecular hierarchies of thermal tolerance in animals. Comp Biochem Physiol A 132:739-761

Pörtner HO (2002b) Environmental and functional limits to muscular exercise and body size in marine invertebrate athletes. Comp Biochem Physiol 133:303-321

Pörtner HO, Peck LS, Zielinski S, Conway LZ (1999) Intracellular $\mathrm{pH}$ and energy metabolism in the highly stenothermal Antarctic bivalve Limopsis marionensis as a function of ambient temperature. Polar Biol 22:17-30

Quadfasel D, Sy A, Wells D, Tunik A (1991) Warming in the Arctic. Nature 350:385

Rhode K (1995) The larger area of the tropics does not explain latitudinal gradients in species diversity. Oikos 79:169-172

Editorial responsibility: Otto Kinne (Editor-in-Chief), Oldendorf/Luhe, Germany
Roughgarden J (1986) A comparison of food-limited and space-limited animal competition communities. In: Diamond J, Case TJ (eds) Community ecology. Harper \& Row, New York, p 492-516

Roy K, Jablonski D, Valentine JW, Rosenberg G (1998) Marine latitudinal diversity gradients: tests of causal hypotheses. Proc Natl Acad Sci USA 95:3699-3702

Sabbadin A (1962) Le basi genetiche della capacita di fusione fra colonie in Botryllus schlosseri (Ascidiacea). Atti Accad Naz Lincei Rend Cl Sci Fis Mat Nat 32:1031-1035

Schmidt GH, Warner GF (1986) Spatial competition between colonial ascidians: the importance of stand-off. Mar Ecol Prog Ser 31:101-104

Sebens KP (1986) Spatial relationships among encrusting marine organisms in the New England subtidal zone. Ecol Monogr 56:73-96

Stebbing ARD (1973) Competition for space between the epiphytes of Fucus serratus. L. J Mar Biol Assoc UK 53: 247-261

Stehli FG, Wells JW (1971) Diversity and age patterns in hermatypic corals. Syst Zool 20:115-126

Swerpel S (1985) The Horsunfjord Fiord: water masses. Pol Polar Res 6:475-496

Tanaka M, Nandakumar K (1994) Measurement of the degree of intransitivity in a community of sessile organisms. J Exp Mar Biol Ecol 182:85-95

Wagnon KA, Loy RG, Rollins WC, Carrol FD (1996) Social dominance in a herd of Angus, Hereford and shorthorn cows. Anim Behav 14:474-479

Węsławski JM, Zajączkowski M, Kwaśniewski S, Jezierski J, Moskal W (1988) Seasonality in an Arctic fjord ecosystem: Horsunfjord, Spitsbergen. Polar Res 6:185-189

Węsławski JM, Wiktor J, Zajaczkowski M, Swerpel S (1993) Intertidal zone of Svalbard 1. Macroorganism distribution and biomass. Polar Biol 13:73-79

Submitted: May 24, 2004; Accepted: August 19, 2004 Proofs received from author(s): December 27, 2004 